\title{
ACADEMIC PREPARATION AND THE INFLUENCE OF IPAD TECHNOLOGY ON MILITARY AND US VETERAN STUDENTS
}

\author{
Joseph Compomizzi, Florida Atlantic University, jcompomizzi@fau.edu \\ Beth L. Sindaco, Florida Atlantic University, bsindaco@fau.edu
}

\begin{abstract}
Studies indicate that enrollment of military and US veterans in college is expected to grow because of benefits available through the Post 9/11 GI Bill and the Yellow Ribbon Program. Likewise, Universities and colleges have undergone studies examining the effect of iPad technology on the academic experiences on students. This article focuses on research of iPad technology and its influences on the academic preparation experiences of US military and veteran students at Robert Morris University located outside of Pittsburgh, Pennsylvania.
\end{abstract}

Keywords: Academic Preparation, Military, U.S. Veterans, iPad Technology

\section{INTRODUCTION}

Mobile technology is making an increasingly prominent presence in the classroom. Specifically, studies continue to analyze the influence of specific technology such as the iPad on the academic and social experiences of different populations of students. Current literature and studies of military and U.S. veteran college students comprise one such sample. Because of factors, which make the military and U.S. veteran population unique on college campuses, an opportunity exists to study the effects of mobile technology on the academic preparation experiences of these students. The purpose of this study explored the utilization and identify the influences portable computing, specifically Apple iPad technology, has on the academic experiences and needs of veterans and military college students. This was examined through the following research questions:

1. What influences does Apple iPad technology have on U.S. veteran and military college students regarding their experiences in Academic Preparation?

2. How do U.S. veteran and military college students employ the use of the Apple iPad academically compared to the use of other technologies such as smart phones, laptops, and desktop computers?

\section{The Profile of Military and Veteran Students}

College enrollment in general is on the rise. Likewise, the number of military and veteran students enrolled in college is growing due to the 2009 and 2011 changes regarding available educational benefits through the Post 9/11 GI Bill and the Yellow Ribbon program. Elliot, Gonzalez, and Larsen [5] reported that in the fall semester of 2010, more than 210,000 veterans and military personnel used Post 9/11 GI Bill educational benefits for college in an undergraduate degree program. While this number does not include those military and veterans enrolled who do not take advantage of the GI Bill's educational benefits or those who are enrolled in a post-undergraduate program, these students represent $4 \%$ of all undergraduates [14].

Those military members and veterans, who qualify for enrollment, according to the U.S. Department of Veterans Affairs, must have served at least 90 days of aggregate service in active duty after September 10, 2001. Also, they must meet one of the following additional requirements: be on active duty currently or honorably discharged from active duty; be honorably released from active duty to retirement or temporary disability retirement; or be honorably released and transferred to either the Fleet Reserves, Fleet Marine Corps Reserves, or for further service in the a reserve component of the Armed Forces. Radford [13] further explains that military personnel or veterans who have been honorably discharged from active duty with a service-related disability and who have served 30 continuous days of service after September 10, 2001 may also qualify for education benefits under the Post 9/11 GI Bill [13].

Veteran students then, for the purpose of this study, are defined as former members of the armed services who are enrolled in an undergraduate, graduate, or doctoral level program of education and meet the preceding requirements 


\section{Issues in Information Systems}

Volume 16, Issue II, pp. 123-132, 2015

of the Veterans Administration. Military service members, on the other hand, are defined as members of the armed services "on active duty, in the reserves, or in the National Guard" and enrolled in an undergraduate or graduate program of education at a college or university who also meet the preceding Veterans Administration requirements of the Post 9/11 GI Bill [13]. Within this enrolled population, as of a study in conducted in 2009 by Radford and Wun [14], $75 \%$ are student veterans and the remaining $25 \%$ is composed of active duty military personnel and reservist students. Of the veteran population alone, nearly two-thirds are enrolled in public universities and colleges [19].

Regarding the characteristics of the military and veteran population, the American Council on Education Issue Brief titled "Serving Those Who Serve" [1] states, "today's student veterans demonstrate many of the characteristics of 'nontraditional' students"' [1]. Student veterans are typically older at ages 23 through 38 compared with their younger traditional college peers. They also tend to have work and family responsibilities and are generally white males even though the number of female veterans and military students enrolled is becoming more significant because of the educational benefits available through the Post 9/11 GI Bill. In addition, student veterans are also enrolled full-time primarily due to the requirements of the GI Bill. "Serving Those Who Serve" [1] also indicates that veteran students are commonly the first generation in the family to attend college coming from the lower and middle quartiles of socioeconomic status [1]. The most recent study by the U.S. Department of Veterans Affairs shows $73 \%$ of post $9 / 11$ veterans were males between the ages of 23 and 38 with $68 \%$ being white and approximately $26 \%$ being African American or Hispanic [13].

The profile for military personnel students is similar. Radford reports that in $2007-08,85 \%$ of military undergraduates were 24 years of age or older [13]. These students also were primarily males with a spouse and children even though the number of females is increasing among this segment of the college student population and is expected to comprise $10 \%$ of the U.S. veteran student population by 2020 [1]. Military students differ from veterans, though, in that they are less likely to be white. Further, $14 \%$ of military students are single parents [13].

The National Survey of Student Engagement (NSSE) in 2010 sheds more light in defining military and veteran college students. This survey polled more than 11,000 student veterans and found that $44 \%$ of them had experienced some type of combat. It also confirmed that this population was more likely to have obligations that "detracted from student pursuits" like families and jobs [19]. The NSSE also found that non-combat veterans spent 52 hours engaged in study, relaxation, and social activities while those military and veteran students who had seen combat spent 59 hours per week in similar activities [19]. According to Sabo, with service members flocking to higher education in greater numbers, degree-granting universities and colleges have been hard-pressed to serve the needs of veteran students, many of whom require additional support to successfully navigate academic life [19].

The sample population for this study was chosen from military and veteran students enrolled through the Veteran Services Office at Robert Morris University located near Pittsburgh, Pennsylvania. This population was chosen because these students received an Apple iPad through a grant from the Commonwealth of Pennsylvania to equip technology veteran and military college students with technology. Of the participants in the study, $5.4 \%$ reported receiving the iPad 2 while the remaining respondents reporting they received the original iPad through the grant awarded the to Veterans Services Office. None of the participants were provided with any other model of the iPad.

\section{Portable Computing and Apple iPad Technology}

Colleges and universities have embarked on experimenting with and studying the effects of portable technology on the academic experiences of students in general. While some schools are incorporating portable computing technology in the toolboxes of students, specifically iPads, on a large scale, other colleges and universities are examining its effectiveness with smaller student populations. It is important to keep in mind that while many institutions are studying the effectiveness and use of iPads by students, the device, compared to other portable computing technologies like smart phones and laptops, is generally new technology introduced only in 2010 with the original iPad. iPad technology is built on Apple's mobile operating iOS system. This platform is built on the concept of human-computer interaction through multi-touch gestures like swiping, pinching, and reverse pinching, touching, and tapping. 


\section{Issues in Information Systems}

Volume 16, Issue II, pp. 123-132, 2015

These Universities are reporting academic benefits in the use of iPads. For example, Fusch [6] at Pepperdine University compared students given iPads with preloaded reading materials and applications to other students in the same course who used laptops and printed books. Preliminary findings of this study showed that iPads increased engagement and collaboration among students and with faculty. The iPads served as a facilitator for more easily sharing information and were less cumbersome than the laptops and books especially in group work [6].

A study at Reed College by Marmarelli and Ringle [11] reported that the study revealed overall high satisfaction by students regarding legibility of text and found it only slightly less suited for data tables, graphs, and formulas. The touch screen enabled students to reach texts and specific passages quickly and navigate between them with ease proving to be very beneficial in classroom participation. The one and one-half pound iPad was reported to be more portable, had battery life twice as long as laptops, and was easily used in a variety of situations. "Because the iPad made it easy for the students to have their entire course readings with them at all times, they found that they read and reviewed the materials more frequently than they would otherwise. The shape and size of the iPad also had a positive effect on classroom dynamics, since the device was either flat or at a slight angle to the desk surface and therefore did not create a barrier between seminar participants, as a laptop screen might [11].”

Marmarelli and Ringle found that students also accessed texts for other courses frequently through the iPads and reported ease with accessing reserved journal articles. One primary benefit identified, however, was the annotation and highlighting capabilities of iPad technology. The ability to highlight in different colors, ability to underscore and draw lines and create free-form drawing was identified as a major advantage over other portable computing devices. While it was observed that paper was still the primary medium for annotation, several students reported that during the semester, as they became more comfortable with the annotation software, the quantity and quality of their notes increased [11]."

Trinity College also studied the effectiveness of iPad technology on pedagogy and learning. As Jennings, Anderson, Dorset, and Mitchell [8] explain in the introduction to the study, "iPads were chosen as the test models primarily because of educational flexibility and value, cost, weight, size, battery life, their low-maintenance, and the fact that the touchscreen technology enabled all learning styles including visual, auditory and kinesthetic" [8] The study identified four benefits of iPad technology to college students. These include increased engagement in learning, individualized content for learning, collaboration, and real time access to information. Students noted that iPads were eco-friendly and more portable than laptops. Information was easily accessed through the device and could be shared without difficulty. In addition, instructors conveyed a primary benefit was the ability of the iPad to present textual and audio-visual materials to students directly for analysis within lessons, thus engaging them more. They further attributed the technology with helping make challenging content less overwhelming as students had immediate access to research terms and concepts immediately through applications and websites as the lessons were presented. Another observation noted by instructors during the study was that the iPad assisted students with making connections beyond their classroom and enabled them to draw on several different media sources in the application of course content to different topics. Overall, the implementation for all students and faculty was recommended by $80 \%$ of the student participants and $76.2 \%$ of faculty and staff participants noting it not as a replacement to laptop or desktop computing, but a compliment to it [8].

Another such university is Seton Hill University in Greensburg, Pennsylvania. Seton Hill issued iPads to every incoming freshman and promotes the use of mobile computing among faculty. They reported, "The use of the iPad and applications we have implemented have resulted in more active participation and more meaningful discussion around issues. We have seen a significant increase in contact between faculty and students as a result of the new channels available for communication" [20].

Moving from non-military based studies with iPad technology, Roberts [15] indicates that the U.S. Naval War College had begun research on iPad's with students and faculty members. The study focused on student habits, perceptions, and preferences in regard to iPad use. As Table 1.1 presents, regarding student responses on study habits and functions, a majority of the participants indicated either that they "frequently" or "always" use the iPad for web browsing, application use, accessing news, and for e-mail. 
Table 1.1. Student Habits with iPads/U.S. Naval War College [15]

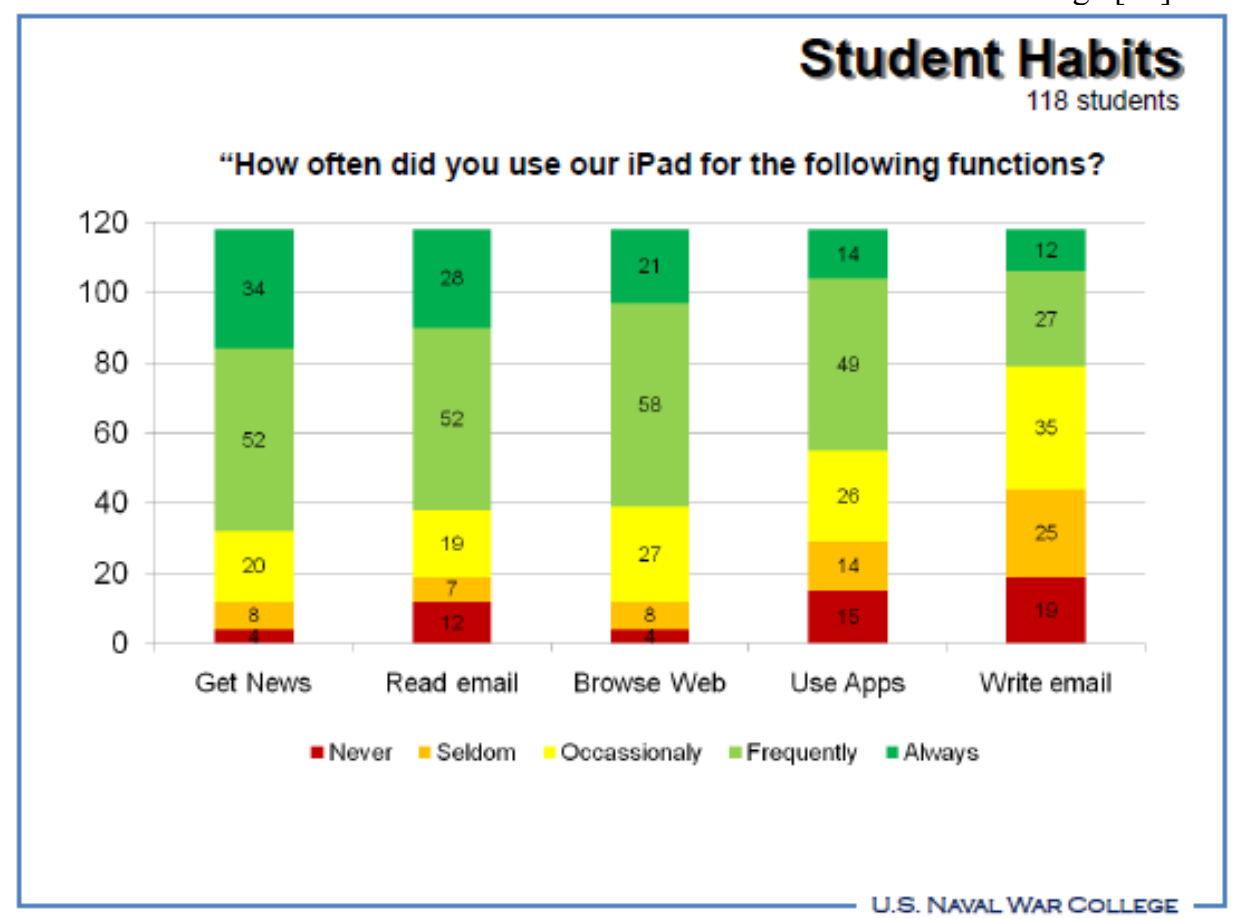

Comparatively more students also indicated that they did not read slower with the iPad than those who indicated they did. In addition when questioned about the uses and benefits of the iPad, the primary feedback given by students included ease of use, reading, annotating, class preparation, and comprehension benefits. While writing papers was also identified as a benefit, most indicated they would still use a laptop or desktop for this function. Overall, $82 \%$ of the sample student population indicated that they would like materials for future courses accessible by iPad technology.

Overall, as demonstrated by these studies, iPad technology is offering benefit to college students and specifically, those with military and veteran backgrounds.

\section{The Academic Experiences and Needs of Military and Veteran Students}

Academically, Livingston [10] identifies veteran and military students as having positive academic transition experiences. These students attribute this positive experience to their military backgrounds and look to academic success as a mission [10]. As well, Livingston concludes that veteran and military students have more academic focus, dedication, discipline, and improved time management from the interviews and observations he conducted. He notes that those who work with veterans have the same observations. Regarding the need for academic support, Livingston's research conveys that most participants note they did not utilize formal academic support because they did not need it as the military taught them self-sufficiency [10]. When utilized, however, military and veteran students seek out other military students for academic assistance and or an academic counselor. This is, in part, due to their perceptions of the culture of the campus. "Participants who held negative perceptions were more likely to reach out to fellow veterans who understood and were sympathetic to their unique circumstances" [10].

Next, regarding personal and demographic dimensions, Ryan [17] draws on the research of Kuh (2008) to emphasize the academic needs of military students and veterans. "Students with two or more of the following characteristics are more likely to drop out of college: being academically underprepared for college, not entering directly after high school, attending part time, being a single parent, being financially independent, caring for children at home, working more than 30 hours per week, or being a first generation college student. Many studentveterans may possess one or more of the characteristics associated with a greater risk of not graduating" [17]. As 
opposed to Livingston, Ryan's findings suggested that some veterans and military students found themselves unprepared academically for the course load of college.

\section{Influences and Effects on Academic Experiences of Military and U.S. Veteran College Students}

In a study conducted by Jensen [9], academic performance and engagement plays a key role in college matriculation and success [9]. Academic performance and engagement includes college GPA, academic discipline, research activities and opportunities, opportunities to join clubs, course load and credits earned. On a related note, Morreale [12] conducted a quantitative study on academic motivation sampling 176 veteran and military college students in order to come to a better understanding of their concept of student success. In it, she links academic discipline as students' reasons for persistence, satisfaction with school, creative thinking skills, and study skills which all contributed to motivation.

\section{RESEARCH METHODOLOGY}

To reiterate, the research questions are:

1. What influences does Apple iPad technology have on U.S. veteran and military college students regarding their experiences in Academic Preparation?

2. How do U.S. veteran and military college students employ the use of the Apple iPad academically compared to the use of other technologies such as smart phones, laptops, and desktop computers?

The model employed for this quantitative study is based on Soy's [21] research of Stake, Simons, and Yin [22]. This model presents a six-step approach. The steps are illustrated in Figure 1.1 as they were completed for this study.

Step one, Determining and Defining the Research Questions: the research questions were defined through an analysis of the qualitative research of Livingston [10] that identified specific academic needs of veterans and military college students and from an article written by Jensen [9] which identified key success factors for at-risk college students. From these studies, deductive reasoning was enlisted to define the construct of Academic Preparation and identify the iPad's influence on the Academic Preparation experiences of US military and veteran college students. For this study, then, the construct of Academic Preparation is defined as researching, completing assignments, reading, note-taking, study skills, and study habits exhibited by military and veteran students.

Step two of Soy's [21] model instructs selection of the case, gather data, and analyze it. For this study, a sample population was chosen from students at Robert Morris University in Pittsburgh Pennsylvania enrolled through the campus Veterans' Services Office. To clarify, veteran and military students also had to be enrolled through the Post 9/11 GI Bill and who received an iPad through a Commonwealth of Pennsylvania grant provided a bounded system to study. There were 267 potential participants of which 83 completed surveys for the study.

Preparing to Collect the Data is Soy's [21] third step of case study research. This included the construction of the survey. The instrument for this study was based on a survey conducted by the U.S. Naval War College for which permission was received to use as a source. Questions were constructed based on the two research questions and a code book developed to cross reference each of the survey questions to one of the research questions. Validity and Reliability was accomplished through two processes: review of the draft survey by two content experts and pilot testing with four veteran students resulting in adjustment to the original survey. Electronic format for the survey was chosen because of ease of distribution and because of time constraints of the study. It was developed in SurveyMonkey because of the ease of programming and the flexibility this software offers for analysis, storage options, and interface with other statistical analysis packages.

The Data Collection step (step four) was completed from late May to end of August, 2012. IRB approval was obtained and three e-mails were sent to potential participants. The distribution list was obtained from the RMU Veterans' Services Offices. Each email yielded additional participation with a final participation rate of $31.09 \%$.

Step 5: Evaluate and Analyze the Data of Soy's [21] model was accomplished through the writing of a Code Book and through file maintenance as the initial actions of data evaluation and analysis. First, the code book was written. 
Data and Variable Files were then built from the code book in SPSS. Additionally, data files created in SurveyMonkey were converted into Excel files and transferred to SPSS for analysis.

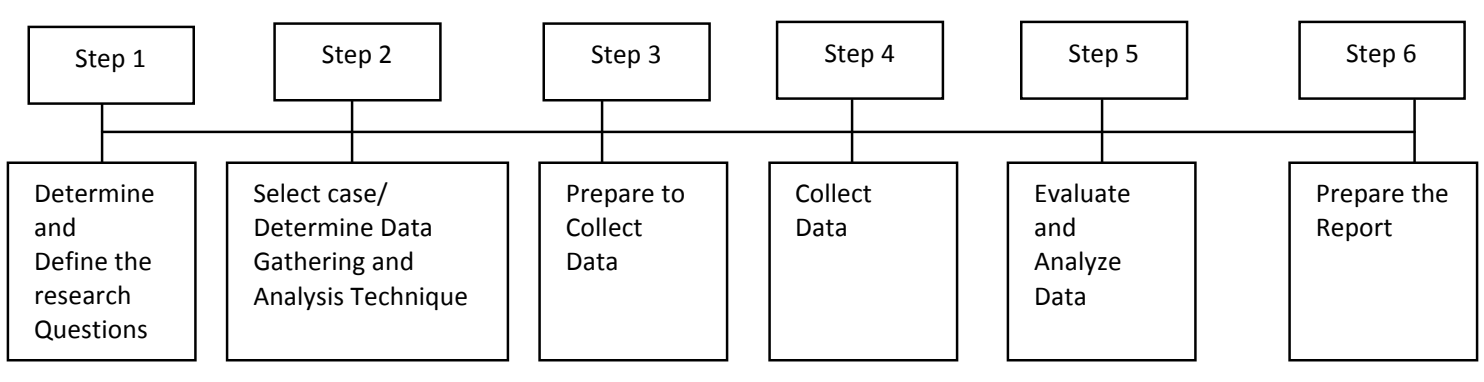

Figure 1.2

\section{RESULTS}

For this study, it was first important to determine if and how the iPad was utilized academically and collaboratively by RMU military personnel and veteran students. This information was ascertained through several questions. When asked if the iPad was their primary computing device, only $20.5 \%$ indicated that it was. Further, when asked to rank the frequency of use among the laptop, the iPad, the desktop and the smart phone, the laptop ranked as the most frequently utilized device as illustrated in Table 1.3.

Table 1.3. Survey Question 19/Frequency of Use by Device

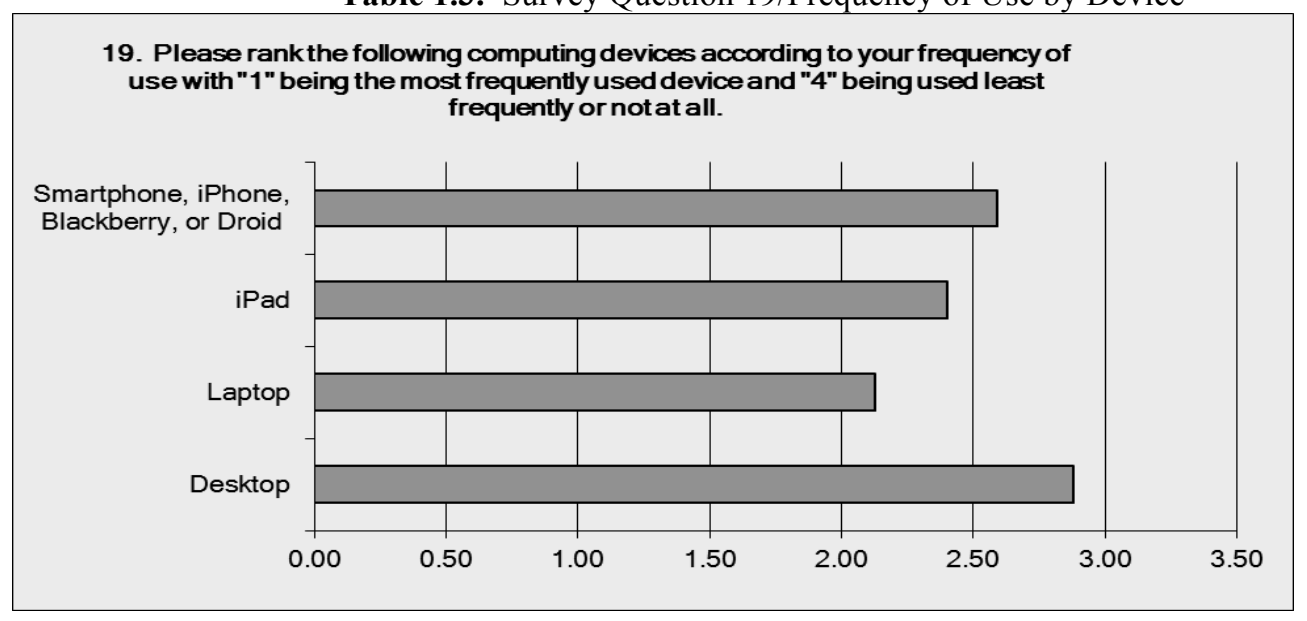

However, the difference between the number of participants indicating their most frequently used device as the laptop and those indicating it as the iPad consisted of only 7 responses. As correlation analysis indicates, the more hours the iPad was employed, the greater its' engagement academically and collaboratively by military and veteran students who participated in the study. This was made especially clear through the Survey Question which asked participants to describe their use of the iPad since receiving it. Results indicated that $71.1 \%$ of the participants "found it easy to use and increasingly useful" while $18.1 \%$ of participants said that they "struggled with it at first, but am using it more and more" best resembles their utilization experience with the iPad. Using the guidelines established by Cohen (1988) in Pallant (2010) regarding Spearman's Rho Correlation Coefficients, positive relationships existed for all behaviors associated with Academic Preparation with coefficients ranging from .351 for use with classroom tasks to .581 for completing homework assignments. 
A survey of the comments yielded an understanding of the non-use and utilization of the iPad academically by RMU veteran and military personnel students. The primary reasons for non-use were the lack of a physical keyboard, the lack of a portable storage device such as a flash or memory stick. Other comments conveyed split use of the laptop and the iPad as one participant wrote, "Not primary, but it's close. I love this thing though. Was contemplating getting one then RMU gave these to us, and it truly is great. Cannot imagine not having one now. Thank you again" and another noted "I use it while on campus. However when I get home, I use my computer." Yet another student commented, "I would have to say yes and no. Because I do have a home computer which i use to write papers for classes. This is something that cannot be done on the ipad. Other than that i my i pad goes with me just about everywhere i go."

Other participant comments conveyed reasoning for utilization of the device academically including portability, ease of use and accessibility to information and data. As one student related, "Good means to have all my school books readily available and easy access to the Internet and the blackboard app." Another participant's comments regarded the dependability of the iPad and provided solution to the issue regarding the lack of a physical keyboard, "i have a keyboard wirelessly designed for it. I like it because of its light weight and sturdiness. It is very reliable, and has applications that $\mathrm{i}$ can use to further benefit note taking and writing up reports. My laptop always overheats, $i$ have had zero problems with my ipad, and i received mine the first year they were issued."

While this research indicates that it may not be the primary computing device, the iPad's frequency of use should not be underestimated. In fact, 44 of the 83 participants, representing $53 \%$ of responses, indicated that they enlist the use of their iPad 1 to 3 hours per day with an additional 25.3\% stating that their iPad is used between 4 and 8 hours each day. In total, then, $78.3 \%$ of participants engage the use of their iPad each day.

Additionally, this study examined what influence iPad technology has on U.S. veteran and military students at RMU regarding their academic preparation experiences. This influence was analyzed through data frequency analysis, correlation analysis, and crosstab analysis. Data frequency analysis reveals that when the iPad was used by the RMU military and veteran students, it is used either always or frequently $37.6 \%$ of the time performing academic preparation tasks and activities. The most frequently noted academic tasks completed with the iPad were webbrowsing, performing research, and performing in-class tasks like note-taking and information look-up. Correlation analysis exhibits that the more hours the iPad was utilized by veteran and military students at RMU, the greater the relationship to its use academically.

In Table 1.4, crosstab analysis comparing if the iPad is the students' primary computing device to academic preparation tasks and activities disclose significant relationships for both. For those who indicated that the iPad was not their primary device, when utilized, $40.1 \%$ of the time it was employed at least occasionally in academic preparation. For those who indicated that the iPad is their primary device, the iPad was employed at least $89.2 \%$ of the time performing academic tasks and activities.

Table 1.4. Cross Tab Analysis of iPad as Primary Computing Device to Use with Academic Preparation Tasks

\begin{tabular}{|l|l|l|l|l|l|}
\hline $\begin{array}{c}\text { Is your iPad your } \\
\text { primary computing } \\
\text { device? }\end{array}$ & \multicolumn{1}{|c|}{ No } & No & Yes & Yes \\
\hline $\begin{array}{c}\text { Academic Preparation } \\
\text { Task/Survey Question }\end{array}$ & $\begin{array}{c}\text { Phi } \\
\text { Co- } \\
\text { efficient }\end{array}$ & $\begin{array}{c}\text { Percentage } \\
\text { indicating } \\
\text { Never or } \\
\text { Seldom }\end{array}$ & $\begin{array}{c}\text { Percentage } \\
\text { indicating } \\
\text { Occasionally, } \\
\text { Frequently, or } \\
\text { Always }\end{array}$ & $\begin{array}{c}\text { Percentage } \\
\text { indicating } \\
\text { Never or } \\
\text { Seldom }\end{array}$ & $\begin{array}{c}\text { Percentage } \\
\text { indicating } \\
\text { Occasionally, } \\
\text { Frequently, or } \\
\text { Always }\end{array}$ \\
\hline 1. Web Browsing & .381 & $12.7 \%$ & $87.3 \%$ & $0.0 \%$ & $100.0 \%$ \\
\hline $\begin{array}{l}\text { 2. Communication } \\
\text { with other } \\
\text { Vets/Military }\end{array}$ & .452 & $38.1 \%$ & $61.9 \%$ & $5.9 \%$ & $94.1 \%$ \\
\hline $\begin{array}{l}\text { 3. Communication } \\
\text { with class peers }\end{array}$ & .484 & $39.7 \%$ & $60.3 \%$ & $29.4 \%$ & $70.6 \%$ \\
\hline 12. Reading & .493 & $49.2 \%$ & $50.8 \%$ & $11.8 \%$ & $88.2 \%$ \\
\hline 13. Classrom tasks & .480 & $44.4 \%$ & $55.6 \%$ & $11.8 \%$ & $88.2 \%$ \\
\hline
\end{tabular}




\begin{tabular}{|l|l|l|l|l|l|}
\hline 14. Homework & .689 & $58.5 \%$ & $41.2 \%$ & $5.9 \%$ & $94.1 \%$ \\
\hline 15. Research & .564 & $38.1 \%$ & $61.9 \%$ & $11.1 \%$ & $88.9 \%$ \\
\hline $\begin{array}{l}\text { Mean for Academic } \\
\text { Preparation Tasks }\end{array}$ & .506 & $40.1 \%$ & $59.9 \%$ & $10.8 \%$ & $89.2 \%$ \\
\hline
\end{tabular}

Cross tabulation comparing the usefulness of the iPad as an academic tool by students and GPA disclosed a positive relationship as illustrated in Table 1.5 . These crosstabs yielded that $28.4 \%$ of participants who either agree or strongly agree that the iPad was a useful academic tool, also had GPA's between 3.6 and $4.0 ; 8.2 \%$ disagree who had a GPA in the same range.

Table 1.5. Cross Tabulation of Schoolwork Usefulness and GPA

\begin{tabular}{|l|l|l|l|l|}
\hline \multicolumn{1}{|c|}{ Response } & \multicolumn{4}{c|}{ GPA } \\
\hline & \multicolumn{1}{|c|}{$\mathbf{3 . 6 - 4 . 0}$} & \multicolumn{1}{c|}{$\mathbf{3 . 1 - 3 . 5}$} & \multicolumn{1}{c|}{$\mathbf{2 . 6 - 3 . 0}$} & \multicolumn{1}{c|}{$\mathbf{2 - 2 . 5}$} \\
\hline Strongly Agree & $12.2 \%$ & $17.6 \%$ & $8.1 \%$ & $0.0 \%$ \\
\hline Agree & $16.2 \%$ & $12.2 \%$ & $2.7 \%$ & $1.4 \%$ \\
\hline $\begin{array}{l}\text { Somewhat } \\
\text { Agree }\end{array}$ & $10.8 \%$ & $1.4 \%$ & $2.7 \%$ & $1.4 \%$ \\
\hline Disagree & $6.8 \%$ & $2.7 \%$ & $0.0 \%$ & $0.0 \%$ \\
\hline Strongly Disagree & $1.4 \%$ & $2.7 \%$ & $0.0 \%$ & $0.0 \%$ \\
\hline Total & $47.4 \%$ & $36.6 \%$ & $13.5 \%$ & $2.8 \%$ \\
\hline
\end{tabular}

An examination of the comments collected on the survey provides indication of the influence of iPad technology on the academic of military and veteran students in this research. While in this study the iPad was not indicated as the primary computing device for the survey respondents in general, survey free-form comments provide valuable insight for both its non-use and academic use. Regarding non-use of the iPad, again, the two primary reasons provided were lack of a physical keyboard and lack of the capacity for a portable storage device. Academically, reasons for non-use include lack of accompanying word processing, spreadsheet, and data base software applications with the device, the feeling that the device was inappropriate for use during class lectures, unavailability of class texts in e-formats, and limited WIFI access. Comments regarding the iPad's usefulness and influence academically are broad ranged. These comments include the ability to take notes, download and read texts, mobility and ease of use, availability of academic apps, ease of look-up and research, quick response time, ease of communication with professors and classmates, and ability to record lectures.

\section{CONCLUSIONS}

As examined in the studies of Elliot, Gonzalez, and Larsen [5] and Radford and Wun [14] the composition of college student population is showing an increase in the number of US military and veteran students. According to the American Council on Education Issue Brief titled "Serving Those Who Serve" [1], this subset of the college population exhibits may of the characteristics of non-traditional students. In addition to the commonly recognized demographics of non-traditional students, these veteran and military student are typically first generation college students coming from the lower socioeconomic quartile and are minorities.

While research is being conducted on military and veteran students, data on the influence and effect of mobile technology is also being collection. Studies at institutions such as Pepperdine, Seton Hill University and the Navy War College are disclosing benefit at various degrees to the academic routines of students. 


\section{Issues in Information Systems}

Volume 16, Issue II, pp. 123-132, 2015

This article, through a study at Robert Morris University, provides further evidence of such benefits specifically to US military and veteran students enrolled and equipped with iPads. Conclusions indicate that while the iPad is not the primary mobile device employed for academic preparation tasks, its influence on those students who have elected it as their primary device is positive. The study at RMU indicates that the more the iPad is used in tasks such as research, note-taking, communicating with peers and other veterans, in-class tasks, annotating, reading and homework, a higher GPA is reported for these students. Student comments attribute these results to ease of use, mobility, availability of academic applications, reliability and portability of the iPad. With the knowledge gained through the study at RMU, possible further research into the use of iPad technology with a with other tablet technology or more current releases of other Apple iPad models such as the iPad Air or iPad Mini with veteran and military college students would yield valuable insight and further broaden that base of knowledge of the effects and influences of iPad technology in higher education.

\section{REFERENCES}

1. American Council on Education (November, 2008). ACE issue brief: serving those who serve: higher education and America's veterans (Issue Brief 1108). Retrieved from:

http://www.acenet.edu/Content/NavigationMenu/ProgramsServices/MilitaryPrograms/serving/Veterans_Issue_ Brief_1108.pdf

2. American Council on Education (2011). Engaging student veterans. Retrieved January 21, 2013 from: http://www.vetfriendlytoolkit.org/campus/engagestu.cfm.

3. Changes to the Post-9/11 GI Bill . (n.d.) United States Department of Veterans Affairs. Retrieved from http://www.gibill.va.gov/benefits/post_911_gibill/Post911_changes.html

4. Compomizzi, J. (2013). The influence of iPad technology on the academic and social experiences of veteran and military students: Academic preparation, collaboration socialization, and information access (Order No. 3565603). Available from ProQuest Dissertations \& Theses A\&I; ProQuest Dissertations \& Theses Global. (1415422512). Retrieved from

http://ezproxy.fau.edu/login?url=http://search.proquest.com/docview/1415422512?accountid=10902

5. Elliot, M., Gonzalez, C., and Larsen, B. (2011). U.S. military veterans transition to college: Combat, PTSD, and alienation on campus. Journal of Student Affairs Research and Practice, 48(3), 267-296. doi:10.2202/1949-6605.6293

6. Fusch, D. (January, 2011). Piloting the iPad. Higher Ed Impact: Weekly Analysis from Academic Impressions. Retrieved December 2, 2011 from http://www.academicimpressions.com/news.php?i=155.

7. Gibill.va.gov/benefits/post_911_gibill/yellow_ribbon_program.html. (November, 2012). Benefits of the yellow ribbon program. Retrieved from: http://gibill.va.gov/benefits/post_911_gibill/yellow_ribbon_program.html

8. Jennings, G., Anderson, T., Dorset, M. and Mitchell, J. (January, 2011). Report on the step forward iPad pilot project. Trinity College. Melbourne, Australia. Retrieved November 4, 2011 from http://www.trinity.unimelb.edu.au/Media/docs/iPadPilotReport2011-1b1e1a52-79af-4c76-b5b6-e45f92f2c9e90. dff

9. Jensen, U. (February, 2011). Factors influencing student retention in higher education. summary of influential factors in degree attainment and persistence to career or further education for at-risk/high educational need students. Kamehameha Schools Research \& Evaluation. Pacific Policy Research Center. Honolulu, HI.

10. Livingston, W. (May, 2009). Discovering the academic and social transitions of re-enrolling student veterans at one institution: A grounded theory. Ph.D. dissertation, Clemson University, United States -- South Carolina. Retrieved September 10, 2011, from Dissertations \& Theses: Full Text.(Publication No. AAT 3355150).

11. Marmarelli, T. and Ringel, M. (2011). The reed college ipad study. The reed institute. Retrieved September 10, 2011 from http://134.10.15.75/cis/about/ipad_pilot/Reed_ipad_report.pdf

12. Morreale, C. (July, 2011). Academic motivation and academic self-concept: Military veteran students in higher education. Ph.D. dissertation, State University of New York at Buffalo, United States -- New York. Retrieved August 30, 2011, from Dissertations \& Theses: A\&I.(Publication No. AAT 3460783).

13. Radford, A. W. (July, 2009). Military service members and veterans in higher education: what the new GI bill may mean for postsecondary institutions. American Council on Education, Washington D.C.

14. Radford, A. W. and Wun, J. (2009). Issue tables: a profile of military service members and veterans in postsecondary education 2007-08 (NCES). National Center for Education Statistics, Institute of Education Sciences, U.S. Department of Education, Washington, D.C. 


\section{Issues in Information Systems}

Volume 16, Issue II, pp. 123-132, 2015

15. Roberts, J. (August 4, 2011). The NWC iPad pilot. U.S. Naval War College. Retrieved November 4, 2011 from http://www.adlnet.gov/wpcontent/uploads/2011/08/roberts_iPad_pilot_naval_war_college_iFest2011.pdf

16. Roberts, J. (Personal communication, January 25, 2012).

17. Ryan, S. (May, 2010). From boots to books: applying Schlossberg's transition model to the transition of today's American veterans to higher education. Master's Thesis, Kansas State University. Retrieved November 22, 2011 from http://krex.k-state.edu/dspace/handle/2097/3862

18. Ryan, S., Carlstrom, A.H., Hughey, K.F. and Harris, B.S. (Spring 2011). From boots to books: applying Schlossberg's model to transitioning American veterans. NACADA Journal, Volume 31, Number 1.

19. Sabo, R. (November 10, 2010). Veterans crave more support in academia, study finds. Retrieved October 14, 2011 from http://www.gibill.com/news/veterans-crave-more-support-in-academia.

20. Seton Hill University. iPad2 for everyone! Retrieved October 2, 2011 from abcnews.go.com/blogs/.../ipadsfor-everyone-at-seton-hill-university

21. Soy, S. K. (Spring, 1997). The case study as a research method. Retrieved from http://www.gslis.utexas.edu/ssoy/useusers/1391d1b.htm.

22. Stake, R. (2010). Qualitative research studying how things work [Kindle Epub Edition]. Retrieved from Amazon.com. 